\title{
Gammel Ribervej og Toftlund toldsted
}

\author{
Af $H$. V. Gregersen
}

Ribes store ælde er nu bevidnet takket være de arkæologiske undersøgelser, der har fundet sted i 1970 'erne. Allerede i 700-årene var Ribe én af vort lands porte ud mod havet, og vikingebyens placering nord for åløbet vidner klart om, at det især har været landtrafikken fra nord og nordøst, altså fra store dele af det nørrejyske område, der har været grundlaget for Ribes storhed $i$ gammel tid. Herfra gik vejen over havet ud til den store verden.

En stor del af den færdsel, der opsamledes i Ribe, er dog også gået videre ad landevejene fra Ribes Sønderport. Ikke mindst gjaldt dette for eksporten af levende dyr, især heste og stude. Da denne handel først for alvor kom i gangi tidlig middelalder vel først med heste og derefter siden slutningen af 1300 årene også med stude - kom landevejstrafikken til at spille den største rolle, men allerede inden da vidner afgrænsningen af Ribe stift i forhold til Slesvig stift (måske foretaget på Knud den Stores tid), at Ribe også har haft et stort sønderjysk opland. Det er karakteristisk for den sydlige afgrænsning af dette opland, at det er Vidåens brede mundingsområde, der har skabt skellet.

I gammel tid betød et bredt åløb en alvorlig hindring for færdselen, og ældre tiders færdsel søgte derfor uden om brede åløb og moser og lerede bakkedrag. Derfor dannedes den jyske halvøs gamle nord-sydgående færdselsstrøg netop der, hvor naturen frembød de færreste hindringer. Hærvejen blev det navn, denne vej har fået.

Også fjerntrafikken ud af Ribes Sønderport fulgte et vejforløb, der søgte uden om alle naturgivne forhindringer. I sydøstlig retning fulgte den $i$ hovedtrækkene vandskellet mellem Gelså (Ribe ås sydlige tilløb) og åerne ved Rejsby, Brøns og navnlig Brede. Sorrebækken ved Hellevad er kun en bæk og stedet - som navnet antyder - et vad. Her var det derfor let at krydse vandløbet, og færdselen kunne uhindret fortsætte, indtil den ved Toldsted blev optaget i Hærvejen eller Oksevejen. Det er denne vej fra Ribe til Toldsted, som i Sønderjylland kaldtes Ribervej eller Gammel Ribervej. Lad os følge den lidt nøjere!

Ved Sønderport i Ribe krydser den åen ved Stampemøllen og går - ik ke langt fra den gamle bispegård Lustrupholm - i sydørstlig retning gennem et oprindelig næsten mennesketomt terræn. Dens sigte er Spandet kirketårn; 
men inden da var Nordhøj ved Fjærsted et godt holdepunkt for den vejfarende.

Op til selve vejen ligger Spandet kro, og det er til dette sted, at det gamle mundheld er knyttet: "Det går an, sagde Spandet præst, da de bar ham fra kirken til kroen! « Hans kirkelige foresatte havde forbudt ham at $g a ̊$ til kros! På tavlen over præsterne i Spandet kirke knyttes udsagnet til Jens Pedersen Møller, der var præst i Spandet fra 1658 til 1682. Det har nok været ham et kærkomment tidsfordriv at opholde sig $\mathrm{i}$ kroen, når vejfarende langvejs fra tog ind her. Sognets egne var der på hans tid kun få af, da ca. $80 \%$ var døde i peståret 1659 .

Spandet er utvivlsomt en meget gammel bebyggelse, og kirkens beliggenhed uden for den egentlige landsby i nærmeste nærhed af Spandetgård er tankevækkende. Er det en genspejling af den førkristelige tids forbindelse mellem helligstedet og den stormand, der forestod kulten? Vi ved det ikke. Ej heller er det sikkert, om det var her, at Sorte Plov havde til huse - den sønderjyske stormand, der i 1137 myrdede Erik Emune. En adelsgård var Spandetgård derimod, indtil den blev udparcelleret $i$ slutningen af 1700årene. Dens kendteste ejer var Claus Sehested, der i 1543 blev lensmand på Riberhus.

Fra Spandet fortsætter Ribervej gennem Spandet Skrøb til Fårmandsbjerg, som man har ment skulle have navn af "de farende mænd ", men vel snarere indeholder et gammelt navn for en fårehyrde. Forbi Arnum og den syd derfor liggende Lindetskov, hvor røvere holdt til, går vejen videre $\mathrm{i}$ retning af Højrup, og dermed er vi ude af Hviding herred.

Toftlund kirke, synlig langvejs fra, udgør det næste naturlige sigtepunkt. I Toftlund boede herredsfogeden for Nørre Rangstrup herred, og her opkrævede sognepræsterne gennem mange år told af de handelsmænd, der færdedes ad Ribervej.

Kirken hed egentlig Herrested kirke, et navn, der endnu anvendtes højt op i 1700-årene, og et af de almindeligt udbredte kirkeflytningssagn fortæller, at det skyldtes, at en røst havde lydt, da kirkens plads skulle bestemmes: „Her er stedet!“ Det har naturligvis intet på sig; men navnet Toftlund er tydeligvis yngre. Det dukker først op efter 1500 for landsbyen nord for kirken, og det er ikke usandsynligt, at sagnet har ret, når det mener, at bebyggelsen blev flyttet efter en brand, idet marknavnet "Brændsand " syd for kirken antagelig peger hen på landsbyens oprindelige plads. Hvis det er rigtigt, skulle man her have chancen for at udgrave en middelalderlandsby.

Herrestedgård ved Toftlund kirke er en udflyttergård inde fra Toftlund by. Toldopkrævningen, som sognepræsterne forestod, foregik derfor ikke her. Den er næppe heller foregået, hvor nu det moderne gadenavn Toldbodgade 
findes. Nej, toldbrættet var - som det hedder i en indberetning fra 1940' anbragt ved landevejen i nærheden af Vestermølle, hvor vejen fra Højrup kom ind $\mathrm{i}$ Toftlund, og herfra gik den videre vest og syd om landsbyen og kirken. Hvor toldbrættet var, skulle kirken egentlig have ligget, fortæller Ove Thorning, der var sognepræst i Toftlund fra 1761 til 1774, i en indberetning om sit sogn, skrevet $1766,{ }^{2}$ Der tales om "det Sted, hvor nu kgl. Toldbrat udhænger (hvor Told nedlægges til Forpagterne i Toftlund med en saare liden Tribut, nemlig 1-2, 3 Sk. af Lossegodset, Købmandsvarer og andet som Potter, Fisk, Træetc. fra Aabenraa til Ribe, som er den alfare Vej, og $1 / 2$ Sk. af hver Stk. Stud af Nør Jylland til Holland eller Hamborg)".

Toftlunds beliggenhed ved alfarvej findes også nævnt $i$ en klage til hertug Hans den Ældre. I 1568 havde Ribe-bispen påduttet de toftlunder en sognepræst, som de ikke syntes om. Han var fra den kongerigske del af stiftet, og de hævdede, at hverken ung eller gammel kunne forstå hans prædikener, fordi han læspede! De klagede derfor til hertugen i Haderslev, deres verdslige øvrighed, og bad ham skaffe sig en anden, og de tilføjede: "helst én, der også evner at udtrykke sig på tysk, eftersom vores kirke ligger ved alfarvej, og der tit kommer både tyske og danske for at høre Guds ord ". ${ }^{3}$ Med omtalen af tyskere menes uden tvivl de mange handelsmænd udefra, hvis vej faldt forbi Toftlund, altså atter engang en understregning af det liv, der rørte sig på den gamle Ribervej.

Inden vi kommer nærmere ind på dette handelsliv, vil vi følge vejen på dens videre forløb i sydøstlig retning. Næste kirkeby er Agerskov, og vejen fra Geestrup til Agerskov kaldes endnu Ribervej. Ligeledes er en stump af den gamle vejbane endnu bevaret ved den lille lokalitet Fårhus sydøst for kirkebyen.

Ved Oksgårde - nævnt 1524, bemærk navnet!-overskrides herredsskellet, og vi er nu i Sønder Rangstrup herred, der ligesom den øvrige del af Åbenrå amt hørte under Gottorp fra 1544 til 1720 . Vejen går østen for Hellevad kirke og landsby, men i nærheden af den fandtes den i ældre tid så bekendte helligkilde ved Hellevad, og $i$ romerkirkens tid, ja $i$ lang tid derefter, har adskillige rejsende gjort holdt her.

Inden Sorrebækken nås, passeres den gamle kro med det ejendommelige navn "Kløver Es«, et navn, der er bevaret fra 1700-årene. Sagnet fortæller, ${ }^{4}$ at en fremmed kom ind i krostuen, hvor nogle mænd sad og spillede kort. Altimens søgte de jæunligt at afstive deres personlighed ved at udstøde grimme eder og forbandelser. Inden længe deltog også den fremmede i spillet, og han tog det ene stik hjem efter det andet. Da hændte det, at en af spillerne tabte et kort. Da han bukkede sig ned for at samle det op, lå det med billedet opad. Det var Kløver Es. Deraf kroens navn! Men samtidig bemærkede han, 
at den fremmedes ene fod var en hestehov. Så vidste han, at det var selveste Fanden, der deltog i spillet, og han fik hurtigt travlt med at forføje sig bort. Som det gik ham, gik det efterhånden også de øvrige spillere, og snart var værten alene med den uhyggelige gæst. Det lykkedes først at blive ham kvit, efter at præsten var blevet hidkaldt og havde fået den onde manet bort.

Der er her tale om et ret udbredt vandresagn. Fanden med heste- eller æselshov kan forfølges helt tilbage til "spotkrucifixet « fra Pompeji (senest år 79 e.Kr.), og kortspillet med den ukendte gæst siger noget om den usikkerhed, der ofte rådede ved alfarvej. Det var en udsat post at bo op til et strøg, hvor alskens mennesker havde deres gang. Ingen kunne her vide sig sikker.

Det sidste stykke af vejen fra Hellevad gik af brug, da broerne blev bygget over vesteregnens åløb. Derfor er det ikke indtegnet på Videnskabernes Selskabs kort fra 1836. Det var tværvejene i retning af Åbenrå, der på det sidste stykke drog trafikken bort fra den gamle Ribervej. På Johannes Mejers kort fra midt i 1600-årene er den derimod klart markeret helt frem til Toldsted. Efter Hellevad passeredes Rødeå ved Hønkys, og derefter er vejen gået østen om Nørre Ønlev, hvor der indtil begyndelsen af 1400-årene var en sognekirke, ${ }^{5}$ og ligeledes østen om Hjordkær kirke, der byggedes kort efter 1520.

Herfra er der ikke langt til Hærvejen, der nås umiddelbart nord for Toldsted. Her var der et vældigt leben. Her skulle der rastes for at betale told, her fandtes der $\mathrm{i}$ den store dam rigeligt med drikkevand til okser og heste, hertil bragte omegnens beboere foder til de mange dyr, og i kroen her kunne der huses mange mennesker. Toldsted ved Hærvejen var simpelthen mødestedet for nær og fjern. ${ }^{6}$

Livet på den gamle Ribervej fortoner sig nutildags i det dunkle. Men meget må være foregået her, da den sammen med Hærvejen udgjorde hovedvejen mellem Sønderjyllands to ældste og største byer, Ribe og Slesvig. Konger og bisper og andre stormænd, der har færdedes mellem disse i vor middelalder så vigtige centrer, har benyttet Ribervej fra Ribe til Toldsted og Hærvejen videre fra Toldsted til Slesvig, og naturligvis også omvendt. Enhver kan i sine tanker ved et studium af vort folks ældre historie finde belæg for denne færdsel.

De sikreste oplysninger om færdselen ad Ribervej giver dog de toldregnskaber, der findes bevaret fra forskellige år i 1500- og 1600-tallet, men det ville være et stort og uoverkommeligt arbejde at gennemgå alle regnskaber fra Ribe-tolden og sammenholde indførslerne med regnskaberne fra toldopkrævningen længere sydfra, f.eks. fra Toldsted, Bov, Gottorp og Rendsburg. Handelshistorikeren Poul Enemark har dog givet et uomstødeligt bevis for denne trafik ved at følge alle de studehandlere, der på en enkelt dag forlod 
Ribe med deres stude.' Han har valgt den 8. september 1501 og sammenholder de studedrifter, der på denne dag forlod Ribe, med toldregnskaberne fra Gottorp, og det viser sig da, at de alle er nået frem til Gottorp toldsted i dagene mellem den 11 . september og den 20 . september 1501 , dog således at hovedparten af studedrifterne var ved Gottorp mellem den 12. og den 14. september. Det skal tilføjes, at frem til Christian 2.'s tid var efterårsdrivningen af størst betydning. Regnskaber fra 1519 og alle de følgende mange år viser, at det siden da var forårs-drivningen, der havde størst betydning.

Fra en række år i 1600-tallet er der bevaret regnskaber fra den toldopkrævning, der fandt sted i Toftlund, og takket være dette materiale er det muligt at skaffe sig en sikker viden om Ribervejs benyttelse som handelsvej. Toldopkrævningen her har skullet give kongens nordligste del af Sønderjylland en indtægt af handelen, inden hertugen af Gottorp tog sin part på Toldsted ved Hærvejen (Åbenrå amt). Derefter opkrævede kongens embedsmænd igen en afgift ved Bov $\mathrm{i}$ det kongelige Flensborg amt, og så kom hertugen atter engang med sin told ved Gottorp toldsted. De handlende måtte således atter og atter punge ud ved de mange passage-toldsteder, der fandtes på hele vejen gennem Sønderjylland, og som også fandtes undervejs gennem Holsten.

Det første toldregnskab fra Toftlund, der er bevaret, er påbegyndt den 1. december 1629 efter afslutningen af Kejserkrigen, og det går til slutningen af april 1630, idet regnskabsåret på den tid gik fra 1. maj til sidste april.

I alt er der bevaret ni efter hinanden følgende regnskaber fra 1629/30 til 1637/38. Derefter savnes et enkelt år, og så følger fire regnskaber fra 1639/40 til 1642/43. Torstensson-krigen medfører en lakune, og først "fra Fienderne droge aff Landett “ (nemlig den 20. oktober 1645) kunne opkrævningen atter tage fart. Der er derefter igen bevaret nogle fortløbende regnskabsrækker, nemlig fem fra $1645 / 46$ til $1649 / 50$ og fem fra $1652 / 53$ til $1656 / 57$. Svenskekrigene afbrød al toldopkrævning mellem 1658 og 1660 , og for Toftlunds vedkommende er de først igen bevaret fra 1669/70 og 1672/73. Derefter følger tre regnskaber fra $1674 / 75$ til $1676 / 77$ og to regnskaber fra $1679 / 80$ og $1680 / 81$. Til sidst er følgende fire enkeltregnskaber bevaret: $1685 / 86,1687 / 88,1689 / 90$ og 1698/99, samt et enkelt fra $1720 .^{8}$ Lad os se, hvilke oplysninger de kan give!

Der er først oplysningerne om studehandelen gennem alle de mange år. Umiddelbart efter Kejserkrigen er det en hamburger, Dietrich Knipper, der i årene fra 1630 til 1633 medfører 398, 250 og igen 250 stude. Ebbe Lassen i Ribe tegner sig i 1630 for 600 stude. Han nævnes ikke siden, og der har nok 


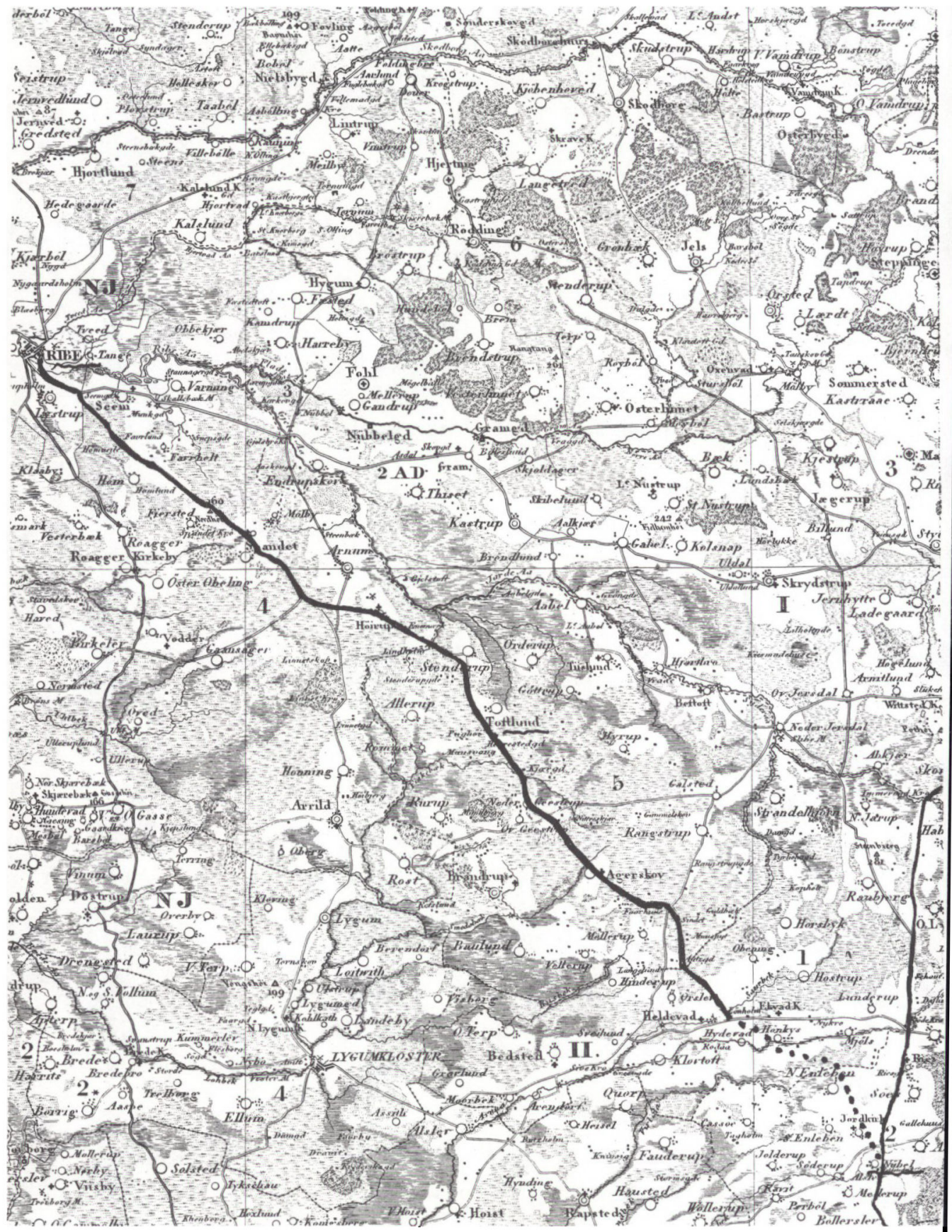

Udsnit af artillerikaptajn $O$. N. Olsens kort over Sonderjylland eller hertugdommet Slesvig, udfort 1836 af Det kgl. danske Videnskabernes Selskab. 
været tale om opstaldede dyr fra krigsårene. I Toldsted-regnskaberne er han næunt $1623 / 24$ og $1626 / 27$. $^{9}$

Trediveårskrigen har tydeligvis virket bremsende på handelslivet ad landevejene. Mens der i 1630 kun gik 998 stude ud af Ribes Sønderport, var der over havnen tale om en eksport på 2.497 stude. I 1631 blev 1.331 stude fortoldet ved Toftlund, $16321.024 \mathrm{og} 1633$ var antallet nede på 782. I sidstnævnte år sendtes der 3.677 stude over Ribe havn, altså atter engang en klar overvægt til søtransporten. Fra 1638 findes endnu et sammenligningsgrundlag. Da gik der 4.882 stude over Ribe havn, men kun 473 ad landevejen. Ribe-historikeren J. Kinch, fra hvem de anførte tal på havnetrafikken stammer, oplyser, at det først er efter 1624 , at der bliver tale om en stor søtransport med stude, ${ }^{10}$ og det synes at bekræfte, at det var krigen, der drog de handlende bort fra landevejen.

I første halvdel af 1600-årene var det især hamburgske studehandlere, der satte deres præg på studeeksporten ad Ribervejen, men efter århundredets

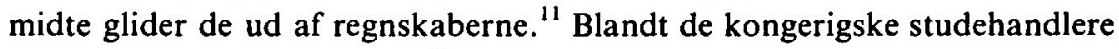
kom en hel del fra Lemvig, ${ }^{12}$ mens Holstebro, Ringkøbing og Varde kun undtagelsesvis nævnes. I $1642 \mathrm{drev}$ Mads Jensen fra Ringkøbing 380 stude forbi Toftlund; men ellers drejede det sig kun om mindre flokke. Handelsmændene fra Lemvig optrådte gerne i kompagniskab, og det kunne tyde på, at de kun har haft begrænset kapital.

Fra 1635 dukker en enkelt ripenser op i regnskaberne. Det er den 29-årige Johan Ratlev, der i 1650 udnæuntes til rådmand og døde 53 år gammel under pesten i $1659 .{ }^{13}$ Han nævnes år efter år med godt et par hundrede stude. I 1646 nåede han op på 308 stude; men efter udnævnelsen til rådmand synes han at have opgivet den risikofyldte studedrivning.

I tiåret 1640 til 1650 optræder en anden ripenser, rådmand og tolder Peder Baggesen, i Toftlund-regnskaberne. Hans bedste år var 1643 med 432 stude. Det var det år, han blev tolder! Ellers holdt også han sig omkring et par hundrede stude om året. Hans fader, Bagge Pedersen, havde før ham været studehandler. Da han var død, havde enken, Margrethe Bagges, 1622/23 sendt stude forbi Toldsted, ${ }^{14}$ men fra 1623/24 var det Peder Baggesen, der fortsatte denne handel indtil sin død i 1650 .

Den tredje ripenser, der javnligt findes i Toftlund-regnskaberne, er borgmester Anders Svane (død 1657). Hans virketid faldt også i 1640'rne, og det højeste eksporttal var 321 stude. Det er - ligesom Johan Ratlevs højeste tal - fra 1646, altså umiddelbart efter Torstensson-krigen.

Fra det nordlige Jylland var det især studehandlere fra Ålborg, der undertiden lagde vejen over Toftlund. Der var også en enkelt fra Randers, Mads Hansen. Blandt ålborgenserne er Christoffer de Hemmer nok den 
kendteste. Han er nævnt i Toldsted-regnskaberne fra $1617 / 18 .{ }^{15}$ I de fleste år har han nok foretrukket Oksevejen gennem Haderslev. Det ses f.eks. i 1641, ${ }^{16}$ men efter 1646 nævnes han år efter år i Toftlund-regnskaberne. I regelen var hans studedrifter på godt 400 stk. Han fortsatte til 1654, og derefter nævnes $\mathrm{i}$ de følgende to år Poul de Hemmer (sikkert en søn).

Af de kongerigske studehandlere nås det højeste eksporttal gennem Toftlund af Laurids Christensen med 700 stude i 1653 og 1.196 i 1654 . Efter sidstnævnte år nævnes han ikke mere; men siden da optræder Bagge Lauridsen, antagelig hans søn, indtil 1677.

Claus Thomsen (Høgh) fra Ålborg kom i gang med sin studehandel i 1648. Han arbejdede sig støt opad med større og større studedrifter og lod i 1675 555 stude fortolde ved Toftlund. Undervejs til Toldsted havde han mistet et enkelt af sine dyr, og her betalte han told for 554 stude. ${ }^{17}$ I 1681 sendte Claus Thomsen 719 stude forbi Toftlund, men hans afløser i eksporthandelen, Anders Jensen (Høgh), var allerede begyndt på egen hånd i 1677, og 1680 optrådte de i kompagniskab. Siden da udviklede Anders Jensen en eksporthandel, der oftest gik ad den østlige Oksevej. ${ }^{18}$ I 1699 sendte han dog 710 stude via Toftlund.

Anders Jensen (Høgh) blev den sidste studehandler fra kongeriget, der holdt de stolte traditioner i hævd fra før Christian 4.'s deltagelse i Trediveårskrigen, og Ålborg blev således den by i kongeriget Danmark, hvorfra der sidst blev drevet studehandel i den store stil.

Men syd for Kongeåen stod deres afløsere parat. De sønderjyske landprangere fra Haderslev, Tønder og Åbenrå amter var ved at overtage en betydelig del af studehandelen. Så tidligt som i 1638 nævnes Jes Møller fra Hellevad vandmølle med 40 stude; men først efter århundredskiftet kom disse handelsmænd fra de sønderjyske landsbyer for alvor i gang. ${ }^{19}$

En anden kreds af studehandlere kom fra Husum og nærmeste omegn (Rødemis, Mildsted, Rantrum etc.). I 1631 passerede Marcus Hansen fra Husum Toftlund med 407 stude; efter 1646 nævnes Carsten Petersen fra samme by med årlige studedrifter på et par hundrede stykker, snart fulgt af Jens Thiessen fra Rantrum. Det var dog først hen i 1670'erne, at Husums handlende rigtigt gjorde sig gældende. Broder Ingwersen fik i 1673291 stude fortoldet $\mathrm{i}$ Toftlund, og i de følgende år nævnes han og andre fra Husum f.eks. i 1686 Hans Ingwersen, Claus Schmidt, Lorenz Owens, Thomas Albrechtsen m.fl. - jævnligt med sammenlagt over 500 stude. $^{20}$

Snart var studehandelen på Ribervejen ligesom på den østlige Oksevej, Hærvejen, dog i hænderne på helt andre, nemlig på handlende fra Nederlandene. Det var en udvikling, der havde taget fart efter afslutningen af Trediveårskrigen i 1648. I 1653 nævnes Gert Jochumsen fra Nijkerk nordøst 
for Utrecht med 600 stude som den første nederlænder, der er fundet $\mathrm{i}$ toldregnskaberne fra Toftlund, men derefter er de også næunt i resten af de bevarede regnskaber, når der ses bort fra krigsårene i 1670'rne, da Louis 14.'s Frankrig angreb deres hjemland.

Det var store flokke, studehandlerne fra de nederlandske provinser Holland, Utrecht, Geldern, Brabant - mødte frem med. I 1655 lod således Gert Petersen fra Weesp ved Amsterdam 1600 stude fortolde ved Toftlund, og år efter år bragte nederlænderne ganske anselige studedrifter forbi dette toldopkrævningssted. Det var helt tydeligt, at det nu var dem, der havde overtaget studehandelen ned gennem den jyske halvø.

I de år, hvor det er muligt at sammenligne studedrivningstallene fra Toftlund med de tilsvarende fra Toldsted ved Hærvejen, ses det, at flere og flere nederlændere siden slutningen af 1670'erne har foretrukket Ribervejen frem for den østlige Oksevej gennem Kolding og Haderslev. Regnskaberne fra året 1699 giver et udmærket sammenligningsgrundlag. I dette år passerede der forbi Toldsted ved Hærvejen i alt 11.620 stude, der ejedes af nederlandske studehandlere, ${ }^{21}$ men af disse havde 7.856 passeret Toftlund! Det vil sige, at Ribervejen er blevet benyttet af godt to tredjedele af de nederlandske studehandlere, nemlig af $67,6 \%$.

De nederlændere, der i 1699 passerede Toftlund, var følgende:

\begin{tabular}{lcc}
\hline & \multicolumn{2}{c}{ Antal stude ved } \\
Navn (efter Toftlund-registeret) & Toftlund & Toldsted \\
\hline Hinrich in De Bettud (skal vare: Betuwe) & 1346 & 1346 \\
Johan van Dam & 632 & 631 \\
Wessel Deutz & 813 & 813 \\
Hieronimus Jacobsen (von Amsterdam) & 1143 & 1143 \\
Ditrich Cleibruch (Toldsted: Kleybrock) & 1244 & 1244 \\
Ditrich Cnöping (Toldsted: Kniping) & 395 & 395 \\
Johan Osterlau & 727 & 727 \\
Hans Stein v. Holland & 845 & 845 \\
Adrian von De Werde & 200 & 206 \\
Thomas Willumsen & 511 & 516 \\
\hline I alt Toftlund: & 7856 stude \\
\hline
\end{tabular}

Nederlændernes kraftige brug af Ribervejen i slutningen af 1600-årene afspejler den strukturændring, der havde fundet sted inden for dansk landbrug. I studehandelens gyldne år før Kejserkrigen talte Odense og de øvrige fynske byer, ja selv København og andre sjællandske byer med blandt studehandelsbyerne; men efter århundredets midte hører man ikke mere om studedrifter fra de danske øer. Derimod fortsatte studeopdrættet uanfægtet $i$ det vestlige Jylland, og her forblev det en væsentlig indtægtskilde helt op til 
det danske landbrugs omlægning i 1870'erne. Det er på denne baggrund, at Ribervejen blev den foretrukne Oksevej frem for Hærvejen. ${ }^{22}$ Efterhånden som der blev lagt broer over åernes nedre, brede løb, kom studedrifterne til at foregå ad den vestlige Oksevej fra Ribe over Tønder til Husum.

På den tid var imidlertid den nederlandske studedrivning forlængst ophørt. I regnskabet fra Toftlund i 1720 savnes den totalt. De største studedrifter forbi Toftlund ejedes da af tre ditmarskere, som i april 1720 førte $80,502 \mathrm{og}$ 105 stude forbi toldopkrævningsstedet.

For at få det fulde udbytte af landevejstrafikken gennem Haderslev amt blev der i 1668 ved siden af de gamle toldopkrævningssteder ved Haderslev og Toftlund indrettet et opkrævningssted ved Neder Jerstal, og her fik toldopkræveren i 1727 endda tilladelse til desuden at "opsætte et toldbræt" ved Over Jerstal, ${ }^{23}$ således at al trafik vest for Oksevejen ned mod Immervad kunne komme til at skæppe i amtets kasse. På samme måde gik det vesterude. Her blev der taget en toldafgift af færdselen ved Lindetskov, Roager og Brøns. ${ }^{24}$

Fra 1720 er der bevaret et sammenligningsgrundlag for stude- og kvægdriften forbi disse tre vestlige toldopkrævningssteder:

\begin{tabular}{cccc}
\hline & Lindetskov, Roager, Brøns & Ndr. Jerstal & Toftlund \\
\hline okser & 103 & 208 & \\
kvæg & 346 & 315 & \\
\hline I alt: & 449 & 523 & 1.337 \\
\hline
\end{tabular}

Det er på denne tid helt tydeligt den sønderjyske bondehandel, der er blevet den dominerende inden for afsætningen af kreaturer.

I sammenligning med studehandelen blegner den øvrige handel med levende dyr ganske og aldeles.

Af størst betydning var hestehandelen, men f.eks. i 1640 blev der $i$ alt kun fortoldet 379 heste, og de er i regnskabet fordelt over ikke færre end 54 indførsler. I nogle ganske enkelte tilfælde er der tale om regulære hestehandlere, der bringer en halv snes heste ad gangen forbi toldstedet. En enkelt fra Ribe havde endda et kobbel på 30 heste med sig. Men ellers er det studehandlere, humleførere og andre handlende, der tager nogle få heste med på deres vej mod syd. Og så er der de mange sønderjyske bønder, der bringer en hest eller et par stykker til nærmeste marked.

Hestehandelen er nogenlunde fordelt over hele året. For bøndernes vedkommende er det de særlige markedsterminer, der er bestemmende for, hvornår hestene føres forbi toldstedet. 
Handelen med svin var kun af ringe betydning. Den 20. september 1640 forte et par svinedrivere fra Ribe 200 svin gennem Toftlund, men - selv om en sådan flok nok har vakt opsigt - var det alt inden for næunte kalenderår.

Derimod var handelen med lam og får noget større. Den lå i hænderne på handelsmænd, der havde specialiseret sig på dette felt, og de kom som regel fra de græsrige egne mod sydvest. I 1630 gjaldt det om Peter Karstensen, "thom Braken " (11/6: 163, 16/7: 143 og 12/8: 160 lam), Matthias Erichsen, Vanderup (17/6: 80, 6/7: 80 og 23/7: 90 lam), Henning Frantzen, Heide (26/5: 150, 24/6: 72, 31/7: 150 og 16/8:160 lam og får). Dertil Hans Swart, Krempe (21/6: 44 lam), Peter "Ditmarsker" (23/7: 50 lam), Dose Godsche, Heide (4/8: 35 lam). Aret efter (23/8 1631) lod Christian Rantzau til Breitenburg 240 lam og får føre forbi toldstedet i Toftlund.

I de følgende år nævnes en handelsmand fra Itzehoe og én fra Eckernförde (Hans John fra "Eggleføhr “). Senere gik handelen med lam og får dog meget tilbage. I 1675 var der en enkelt fra Flensborg med 40 lam, og så Jes Petersen fra Toftlund med sammenlagt 149 lam og får, som han til dels havde købt på Nybøl gods ved Gram, men det var også alt.

Bort set fra studehandelen var handelen med levende dyr således ret beskeden.

Toftlund-regnskabernes væsentligste betydning ligger nok i det bidrag, som de yder til belysning af landhandelen tværs gennem den nordlige del af Sønderjylland.

En af hovedindførselsvarerne var humle til ølbrygningen, og det var i 1600årene hovedsagelig humleførere fra Gardelegen i Altmark nord for Magdeburg, der havde specialiseret sig i denne handel. Kun i få tilfælde nævnes der også handlende fra det nærliggende Haldensleben og fra Braunschweig.

Humleførerne betalte som regel told pr. humlekærre, men undertiden også pr. sæk humle, og det årlige antal kærrer på Ribervejen svingede gerne fra godt ét hundrede til henimod to hundrede. I nogle få år kunne antallet dog synke til ned imod et halvt hundrede. En sammenligning med det antal humlekærrer, der i det samme tidsrum passerede Haderslev toldsted, giver til resultat, at trafikken med humle alt i alt var noget større på Oksevejen fra Immervad til Kolding; men også her hørte det dog til sjaldenhederne, når der i Haderslev blev fortoldet mere end to hundrede humlekærrer. ${ }^{25}$

Humleførerne forsøgte gerne at skaffe sig en vare med tilbage som returfragt; det ville jo øge udbyttet af rejsen. Hertil egnede sig alle mulige danske landbrugsprodukter, såsom smør, flæsk, huder etc., der kunne tages med på kærrerne. Til belysning af denne form for handel skal nogle få eksempler fremdrages fra Toftlund-regnskabet for året 1630 : 
Steffen Berns, Gardelegen:

1630 14/8: 3 kxrrer humle, samme dag "Endnu tillbage fra Ribe " med en hest; 17/9: 2 kærrer; 26/10: 1 karre, 4/1/ og 7/11: 2 tønder smør; 5/12: 1 kærre; 10/12: 2 tønder smør.

Michel Bunemann, Gardelegen:

1630 8/4: 1 kærre; 17/4: 1 kærre; 20/4: I tonde talg; 6/8: 2 kærrer; 1//9: 1 kærre; 23/10: 2 kærrer, 29/10: 1 hest og $1 / 2$ tonde smer.

Güntzel Dornbusch, Gardelegen:

1630 5/2: 2 kærrer; 5/3: 1 dege huder; 26/3: 2 kærrer; 20/11: 1 kærre; 5/12: 1 kærre; 10/12: 2 tronder smar.

Hans Gagelmann, Haldensleben:

1629 17/12: 2 kærrer; 1630 16/1: 1 skippund gods; 20/4: $2 \mathrm{kxrrer} ; 10 / 5: 2 \mathrm{kxrrer;} 30 / 5: 2 \mathrm{kxrrer,}$ 10/6: 1 tønde smør; 8/8: 2 kærrer; /3/8: 1 skippund flæsk og 1 hest; 18/9: 2 kærrer; $2 / 11: 1$ kærre, 30/12: 1 dege 1 , ler.

En handelsvare, der jævnligt påkalder sig opmærksomhed på grund af de mange indførsler i toldregnskaberne, er hør til fremstilling af lærred. År efter år lader småhandlende især fra Flensborg, men også nogle enkelte fra Ábenrå, hør fortolde i Toftlund. I regelen drejer det sig om kvantiteter på fra $1 / 2$ til 3 skippund ad gangen, og da der $\mathrm{i}$ maj/juni 1630 var tale om i alt 80 skippund og i september samme år om 82/ $\frac{1}{2}$ skippund - og ti år senere $\mathrm{i}$ $\mathrm{maj} / \mathrm{juni} 1640$ om 124 skippund og i september 1640 om 123 skippund - giver det naturligvis anledning til overordentlig mange indførsler i regnskaberne.

I de følgende årtier gik denne handel øjensynligt en hel del tilbage; men det kan give anledning til, at det spørgsmål melder sig: hvor repræsentative er $\mathrm{i}$ grunden de bevarede toldregnskaber?

Vi ved nemlig, at der i 1600-årenes slutning blev indført ret så betydelige mængder af hør fra de baltiske havne, især fra Riga. Tilbagegangen kan derfor skyldes, at der kun blev betalt told af hjemmeavlet hør (fra Angel, Sundeved m.m.), mens importeret hør har været toldfrit, fordi der var blevet betalt told ved indførselen over havnen, den såkaldte »licent«. Vi ved nemlig fra licent-regnskaberne fra Åbenrå havn, ${ }^{26}$ at der foruden hør er blevet sendt betydelige mængder af tømmer og træprodukter ind i Nordslesvig ad landevejene - også ad Ribervej - men regnskaberne fra Toftlund melder intetsomhelst herom. Kun de varer, der var toldpligtige, findes indført $i$ toldregnskaberne, en kendsgerning, der ikke bør glemmes.

Eldre tiders kornhandel er det også ofte vanskeligt at belyse ved hjælp af toldregnskabsmateriale. Der var jo dengang stort set tale om et selvforsynende samfund, og var der knapt med korn, ja, så måtte man spænde livremmen ind eller simpelthen sulte. Det var de barske vilkår i de såkaldt "gode, gamle dage $\times !^{27}$

Når høsten havde været utilstrækkelig, blev der nu og da af regeringerne udstedt forbud mod eksport af korn, men den slags hindrede jo ikke den indenlandske omsætning af korn, og her giver Toftlund-regnskaberne den 
interessante oplysning, at der hvert år blev sendt rug i retning af Ribe, altså til Vestjyllands magre egne, og dette korn blev leveret af bønder fra strøget mellem Toftlund og Åbenrå. I 1630 var der tale om $89 \frac{1}{2}$ tønde rug, og den, der i dette år kom længst borte fra, var en bondemand fra Uge ved Tinglev. I 1640 er transporten af rug forbi Toftlund opgjort til sammenlagt 308 tønder, hvortil der kom nogle tønder tadder (boghvede) og malt (af byg).

I de følgende årtier er der helt stille om kornhandelen, og det skyldes utvivlsomt, at tolden på korn er blevet ophævet. En korntold vil jo altid virke fordyrende, og som en afgift på det daglige brød rammer den samfundets dårligst stillede hårdest. Det var også småkårsfolk, der var de hårdest ramte, når kornkræmmerne - som Niels Heldvad oplyser ${ }^{28}$ - "gemte til en dyrere tid «, inden de solgte deres korn. Toftlund-regnskaberne bekræfter den gamle præst og kalendermands påstand, idet det tydeligt ses, at rughandelen altid var på sit højeste, umiddelbart før den nye høst var $\mathrm{i}$ hus.

Markedernes overordentlig store betydning for den indenlandske vareomsætning fremgår af indførsler fra 1600-årenes sidste årtier (idet de anførte datoer selvsagt er det tidspunkt, da den handlendes vare er indført $i$ Toftlundregnskabet):

\begin{tabular}{lcccc}
\hline Marked & $1685 / 1686$ & $1687 / 88$ & $1689 / 90$ & $1698 / 99$ \\
\hline Åbenrå & $4 / 7$ & $6 / 7$ & $6 / 7$ & $? / 7$ \\
Tønder & $5 / 8$ & & $5 /-7 / 8$ & \\
Kliplev & $18 / 8$ & $12 / 8$ & $14 / 8$ & \\
Løgumkloster & $22 /-24 / 8$ & & $19 / 8$ & \\
Flensborg & $26 /-27 / 9$ & $17 / 9$ & & $? / 9$ \\
Åbenrå ("Gallus«) & $3 /-10 / 10$ & $1 /-10 / 10$ & & $10 / 10$ \\
Kliplev & $15 / 3$ & $14 / 3$ & $6 /-9 / 3$ & \\
Løgumkloster & $8 / 4$ & $4 /-7 / 4$ & $6 / 4$ & \\
\hline
\end{tabular}

Toldopkræverne i Toftlund var først sognepræsten fra 1615-1648, Marcus Stuer, i perioden $1639 / 40$ til $1656 / 57$ afløst af tingskriver Niels Jepsen. Derefter er det atter sognepræsten, nemlig Anders Clausen (Slange), der forestår opkrævningen. Han var præst i Toftlund sogn 1648-1704.

\section{NOTER}

1. Sønderjyske Stednavne, Haderslev Amt, s. 665 . - Om kirkeflytningssagnet, se: H. V. Gregersen: Senderjyske kirkeflytningssagn (Sønderjysk Månedsskrift 1952, s. 145-150).

2. Sønderjyske Årbøger 1913, s. 157.

3. H. V. Gregersen: Plattysk i Sønderjylland, 1974, s. 338-339.

4. Frederik Fischer: Slesvigske Folkesagn, 1929, s. 403-405; Peter Hansen: Småglimt fra Hellevad sogn, 1980, s. $23 f$. 
5. H. V. Gregersen: Forsvundne kirker langs med Hærvejen i Nordslesvig (Sønderjysk Månedsskrift 1974, s. 237ff.). En arkæologisk undersøgelse i 1981 ved Birgitte Wistoft har fastslået Ønlev kirkes nøjagtige placering.

6. H. V. Gregersen: Toldsted ved Harvejen, 1978.

7. Poul Enemark: Studier i toldregnskabsmateriale fra begyndelsen af det 16. århundrede, II, 1971, s. 200; Toldsted ved Harvejen, s. 65.

8. Toldregnskaberne ligger som bilag til Haderslev amtsregnskaber for de págældende år (Rigsarkivet).

9. H. V. Gregersen: Toldsted ved Hærvejen, 1978, s. 103. Smstds. s. 106 findes Diedrich Knöper nævnt under Hamburg.

10. J. Kinch: Ribe Bys Historie og Beskrivelse II, 1884, s. 827.

11. Der navnes: Diedrich Grove, Hinrich Arndts, Jochen Jastrum, Hinrich Filter, Arndt v. Ginckel, Johann Göcken. Sidstnæunte i 1653, og derefter forekommer der ikke mere hamburgere i de regnskaber, der er bevaret.

12. Handelsmandene fra Lemvig var Oluf Jensen, Per Trans, Peder Lang, Anders Høst, Jens Høst, Christen Simonsen og Jacob Olufsen (søn af førstnavnte?). Smlgn. iøvrigt: Toldsted ved Hærvejen, s. 102.

13. Personalier fra Ribe i disse år efter: Ole Degn: Livet i Ribe 1560-1700 i samtidiges optegnelser, 1971.

14. Toldsted ved Harvejen, s. 103.

15. Smstds., s. 104.

16. Smstds., s. 124.

17. Smstds., s. 132.

18. Sammenlign smstds., s. 152.

19. Om det sønderjyske landprangeri, se: Toldsted ved Hærvejen, s. 149-15I.

20. Toldsted ved Harvejen, s. 152.

21. Smlgn. tallene i: Toldsted ved Hærvejen, s. 145-146. Det vil her ses, at tolderen i Toldsted som oftest meddeler den lokalitet, hvorfra den handlende stammede, mens det $i$ Toftlundregnskaberne kun angives i nogle få tilfælde.

22. Dette forhold er ikke blevet pảagtet i: Ludwig Andresen: Zur Geschichte des Viehhandels im Amte Tondern og i hans Geschichte der Stadt Tondern bis zum dreissigjährigen Krieg, 1939. Her er der derfor fortrinsvis tale om udskibning af stude over Tonder og Højer.

23. H. V. Gregersen: Egnen omkring Vojens, 1977, s. 184.

24. Ludwig Andresen har i Zur Geschichte des Viehhandels im Amte Tondern benyttet materialet fra de mange smá toldopkrævningssteder inden for det gamle Tønder amt.

25. Jvf. Th. O. Achelis: Vom Hopfenhandel (Deutscher Volkskalender 1943, s. 80-85).

26. H. V. Gregersen: Bidrag til Aabenraas økonomiske historie indtil ca. 1730 (Sønderjyske Årbøger 1949, s. 56-91).

27. Jvf. Lars N. Henningsen: Misvækst og kornspekulation (Sønderjyske Årbøger 1981, s. 5-56).

28. H. V. Gregersen: Niels Heldvad. En biografi, 1957, s. 80ff.; sm.: Slesvig og Holsten indtil 1830, 1981, s. 290. 